Gynecol Obstet Invest 1989;28:I-IV

\title{
Contents, Vol. 28, 1989
}

\section{No. 1}

No. 2

Original Paper

Effects of Histamine and Serotonin on the Contractility of Iso

lated Pregnant and Nonpregnant Human Myometrium

Cruz, M.A.; Gonzalez, C; Acevedo, C.G.; Sepulveda,

W.H.; Rudolph, M.I 1

Endometrial Reaction to Intrauterine Device in Pregnancy

Ezra, Y.; Birkenfeld, A.; Levij, I.S 5

Birth Weight and Thyroxine-Binding Globulin in Pre-Eclampsia Lao, T.T.; Chin, R.K.H.;

Panesar, N.S.; Lam, Y.M. ... 8

CA 125 in Human Milk and Serum

Fuith, L.C.; Daxenbichler, G.; Marth, C

Premature Rupture of the Fetal Membranes, the Phases of the

Moon and Barometer Readings

Trap, R.; Helm, P.; Lidegaard, O.; Helm, E 14

Use of Cefuroxime in Preventing Postcesarean Infection in

High-Risk Patients

Moberg, P.J.; Schedvins, K 19

Familial Clustering in the Polycystic Ovarian Syndrome

Lunde, O.; Magnus, P.; Sandvik, L.; Høglo, S

Suppression with Gonadotropin-Releasing Hormone Analogues Prior to Stimulation with Gonadotropins: Comparison of Three Protocols

Lipitz, S.; Ben-Rafael, Z.; Dor, J.; Shalev, J.; Elenbogen, A.;

Levran, D.; Serr, D.M.; Mashiach, S 31

Dehydroepiandrosterone Sulfate in Postmenopausal Women: Lack of Influence of Parity

Carlström, K.; Lagrelius, A.; Lunell, N.-O.; Möllerström,

G.; Rannevik, G.; von Schoultz, B 35

Plasma Retinol-Binding Protein in Human Uterine Cervical

Dysplasias and Cancer

Palan, P.R.; Basu, J.; Romney, S.L 38

Significance of Initial Plasma Steroid Concentrations in the Prognosis of 'Nonendocrine' Malignant Ovarian Tumors

Mählck, C.-G.; Bäckström, T.; Kjellgren, 041

Serum Lactic Dehydrogenase and Primary Carcinoma of the

Ovary

Younis, J.S.; Zeevi, D.; Hadani, P.E.; Anteby, S.0

Original Paper 
Histochemical Localization of Vasoactive Intestinal Polypep-tide and Its Influence on Contractile Activity in the Non-Pregnant and Pregnant Human Cervix Bryman, I.; Norström, A.; Lindblom, B.; Dahlström, A. . 57

Morphological Development of the Human Placenta in Normal and Complicated Gestation: A Quantitative and Ultra-structural Study

Biagini, G.; Vasi, V.; Pugnaloni, A.; Valensise, H.; Rizzoli, R.; Miccoli, M.C.; Mazzanti, L.; Cester, N.; Romanini, C. 62

Renal Function in the Newborn. Newborn Creatinine Related to Birth Weight, Maturity and Maternal Creatinine Lao, T.T.; Loong, E.P.L.; Chin, R.K.H.; Lam, Y.M. ... 70

Influence of Progesterone on the Sodium and Potassium Con centrations of Rat Uterine Fluid Investigated by Microdialysis

Nordenvall, M.; Ulmsten, U.; Ungerstedt, U 73

The Effect of Magnesium on Calcium Uptake and Contractil

ity in the Human Myometrium

Popper, L.D.; Batra, S.C.; Åkerlund, M 78

Levels of Protein S during the Normal Menstrual Cycle and in Women on Oral Contraceptives Low in Estrogen

Jespersen, J.; Nielsen, M.T 82

Estrogen-Binding Protein in Blood and Follicular Fluid, and Its Biochemical Properties in Human Females

Saito, N.; Kanasugi, H.; Kimura, K.; Suzuki, T.; Komiya, Y.; Ogawa, H.; Hiroi, M 87

Gamma-Aminobutyric Acid, Its Related Enzymes and Recep tor-Binding Sites in the Human Ovary and Fallopian

Tube

László, Á.; Villányi, P.; Zsolnai, B.; Erdö, S.L 94

Anaerobic Vaginosis: Treatment with Tinidazole Vaginal Tab

lets

Heikkinen, J.; Vuopala, S 98

Colposuspension and Transvaginal Bladder Neck Suspension

in the Treatment of Stress Incontinence

Penttinen, J.; Kaar, K.; Kauppila, A 101

Case Reports

Successful Outcome of Pregnancy Complicated by Giant

Myoma and Severe Heparin-Induced Osteopenia

Silber, M.; Ölund, A 51

Unexpected Nature of a Pelvic Mass in Pregnancy: Castle-man's Disease

Baser, í.; Dilek, S.; Pabuçcu, R.; Ülgenalp, í.; Mermut, S.;

Finci, R 53

Announcements $\quad 56$

Case Reports

Fatal Disruption of a Splenorenal Shunt after Multiple Preg

nancies

Walden, R.; Ben-Rafael, Z 106 
Chorioangioma of the Placenta

Lopez, H.B.B.; Kristoffersen, S.E 108

Short Communication

Ultrasonographic Measurement of the Fetal Transverse Cerebellum in utero

Hata, K.; Hata, T.; Senoh, D.; Makihara, K.; Aoki, S.;

Takamiya, O.; Kitao, M Ill

Announcements

81

IV

Contents

No. 3

No. 4

Review

45, X Streak Gonad Syndrome Associated with Bilateral 'Burnt

Out' Gonadoblastoma

Bčsze, P.; Magyar, É.; Tóth, A.; László, J 113

Original Paper

Changes in Fatty Acid Composition of Cervical Mucus Leci

thin during Pregnancy

Pschera, H.; Larsson, B.; Kjaeldgaard, A 118

Mechanical Stretching Increases Prostaglandin E2 in Cultured

Human Amnion Cells

Kanayama, N.; Fukamizu, H 123

Apolipoproteins in Human Amniotic Fluid: Concentrations, Isoforms and Polymorphism

Steinmetz, A.; Sefraoui, M.; Scheffler, E.; Czekelius, P.;

Barkia, A.; Bard, J.-M.; Parra, H.-J.; Fruchart, J.-C; Kaf-

farnik, $\mathrm{H} \quad 127$

Changes in Serum Calcium, Magnesium, Cyclic AMP and

Monoamine Oxidase Levels during Pregnancy and under

Prolonged Ritodrine Treatment for Preterm Labor

Kawarabayashi, T.; Tsukamoto, T.; Kishikawa, T.; Sugi-

mori, $\mathrm{H}$ 132

Reduction of Hydroxyproline Content in the Vessels of the

Human Umbilical Cord in Premature Rupture

Andreucci, D.; Teodoro, W.R138

Fetal Motorical and Heart Response to Sound Stimulus in Dif

ferent Behavioral States

Weiner, E.; Serr, D.M.; Shalev, E 141

Calcium Antagonists for Uterine Relaxation

Lechner, W.; Marth, Ch.; Keene, F 144

Gonadotropin and Ovarian Steroid Production in Polycystic Ovarian Syndrome during

Suppression with a Gonadotro-pin-Releasing Hormone Agonist Tanbo, T.; Åbyholm, T.;

Magnus, 0.; Henriksen, T. . . 147 
Repetitive Ovarian Response to Gonadotropin Stimulation in an in vitro Fertilization Program Wheeler, C; Ben-Rafael, Z.; Benjamini, Y.; Blasco, L.;

Flickinger, G.; Tureck, R.W.; Mastroianni, L 152

Bacterial Vaginosis Is Not a Simple Ecological Disorder

Fredricsson, B.; Englund, K.; Weintraub, L.; Ölund, A.;

Nord, C.-E 156

Short Communication

Amniotic Fluid Selenium Status in Pre-Eclampsia

Roy, A.C.; Ratnam, S.S.; Karunanithy, R 161

Case Reports

Pregnancy following Oocyte Donation and in vitro Fertiliza

tion after Failed Attempts at Donor Uterine Lavage

Sauer, M.V.; Paulson, R.J 163

Abnormally High Values of CA 125 and CA 19-9 in Women with Benign Tumors

Nagata, H.; Takahashi, K.; Yamane, Y.; Yoshino, K.; Shi-

bukawa, T.; Kitao, M 165

Original Paper

Results of the Use of a Pure Urinary FSH Stimulation Regime

in Patients Unsuccessfully Treated with hMG in an in vitro

Fertilization Program

Grillo, M.; Buck, S.; Freys, I.; Mettler, L 169

Mode of Delivery and Lymphocyte 32 -Adrenoceptor Density

in Parturients and Newborns

Santala, M 174

Fetal Demise Associated with Lupus Anticoagulant: Clinical Features and Results of Treatment

Carp, H.J.A.; Frenkel, Y.; Many, A.; Menashe, Y.; Ma-

shiach, S.; Nebel, L.; Toder, V.; Serr, D.M 178

Fibronectin and Postpartum Infection in Rabbits: An Animal Model

Bawdon, R.E.; Fiskin, A.M.; Little, B.B.; Davis, L.L.; Ver-

garra, G 185

Rabbit Plasma Fibronectin Levels Associated with Staphylo-

coccus aureus Enterotoxin B: An Acute-Phase Reaction

Bawdon, R.E.; Davis, L.E.; Little, B.B 191

Antenatal Measurement of Scapula Length Using Ultrasound

Murao, F.; Shibukawa, T.; Takamiya, O.; Yamamoto, K.;

Hasegawa, K 195

Ultrasonic Evaluation of Liver Development in the Fetus in utero

Murao, F.; Senoh, D.; Takamiya, O.; Yamamoto, K.; Hase

gawa, K.; Kitao, M 198

Incidence of Adhesions in the True Pelvis after Pelviscopic Operative Treatment of Tubal

Pregnancy Mecke, H.; Semm, K.; Freys, I.; Argiriou, Ch.; Gent, H.-J. 202

Naproxen Sodium in the Treatment of Premenstrual Symptoms. A Placebo-Controlled Study

Facchinetti, F.; Fioroni, L.; Sances, G.; Romano, G.; Nap-

pi, G.; Genazzani, A.R

205

Ultrasound Assessment of the Bladder Volume after Anterior Colporrhaphy 
Paltieli, Y.; Degani, S.; Aharoni, A.; Shapiro, I.; Reiter, A.;

Scharf, M.; Weiss, A 209

Urinary Polyamine Excretion Patterns in Patients with Epithe lial Ovarian Cancer

Lawton, F.; Griffin, M.; Slack, J.; Blackledge, G 212

Comparative Analysis of the Inherent Radiosensitivity of Ovarian Carcinoma

Rotmensch, J.; Beckett, M.A.; Toohill, P.; Weichselbaum,

R.R.; Schwartz, J.L 215

Author Index 219

Subject Index 220

Announcements

151,155 